\title{
THE WAY WE WERE
}

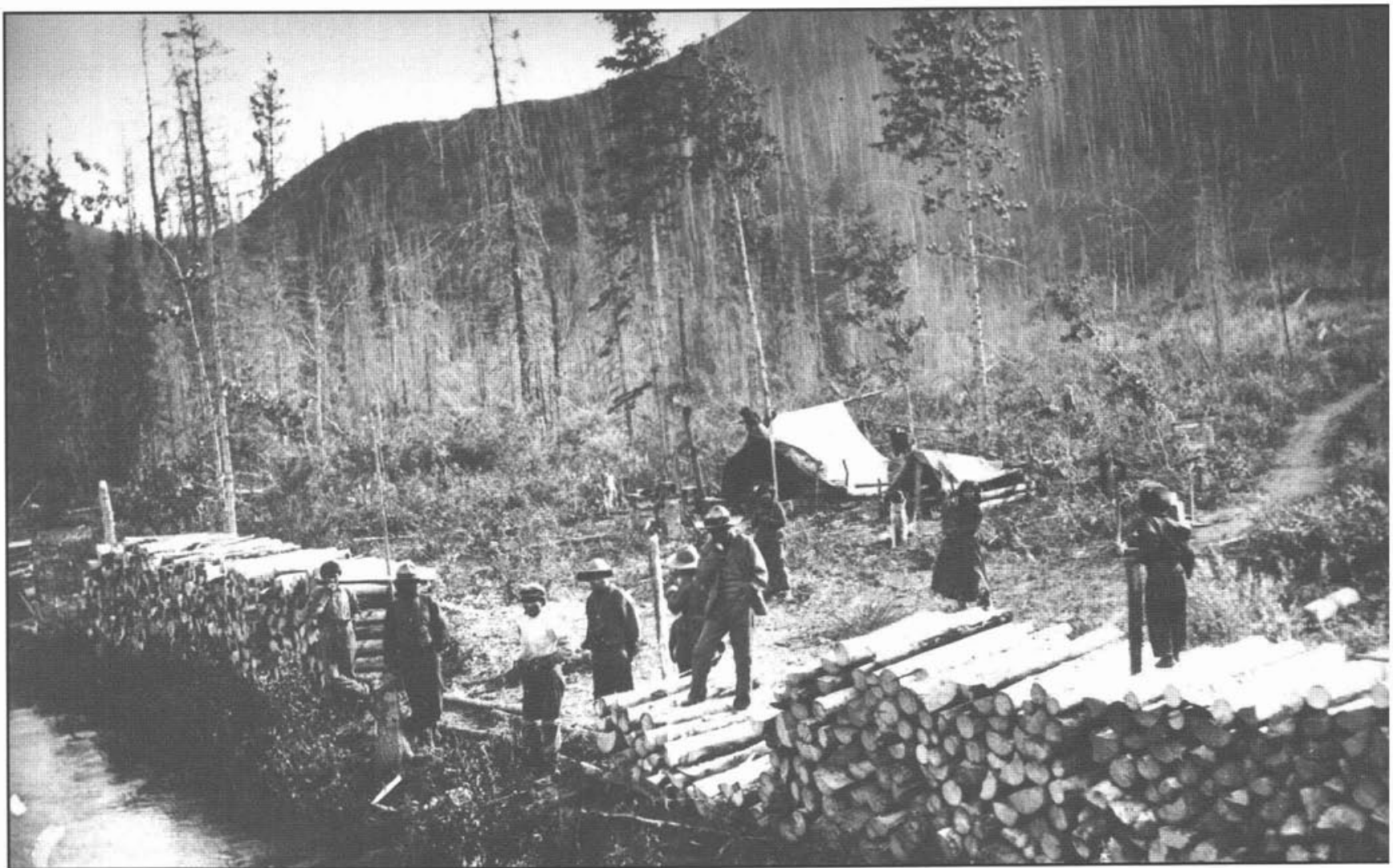

Above: Waiting to load firewood on steamer. Yukon River, July 1900.

\section{Yukon sternwheelers 1898 - 1956 fuelwood needs}

A t the height of the Gold Rush, approximately 250 sternwheelers plied the rivers of the Yukon and Alaska. Woodcutters' camps and settlements were located approximately 25-30 miles apart, along the Yukon River from Lake Bennett to the Yukon/Alaska Boundary north of Dawson.

The river steamers traversed the Yukon River between Whitehorse and Dawson City, a distance of 460 miles, from 1898 to 1956 . On the downstream run a sternwheeler burned about 80 cords and approximately 180 cords for the return journey, at the rate of 1 to 2 cords per hour. Every 4 to 5 hours they would stop for fuelwood at one of the woodcamps along the river. Cords of wood were usually cut and hauled to the riverbank in the winter. Wood had to be 4 feet long, not more than $8^{\prime \prime}$ at the butt or less than 4" at the small end. Smaller boats used $3^{\prime}$

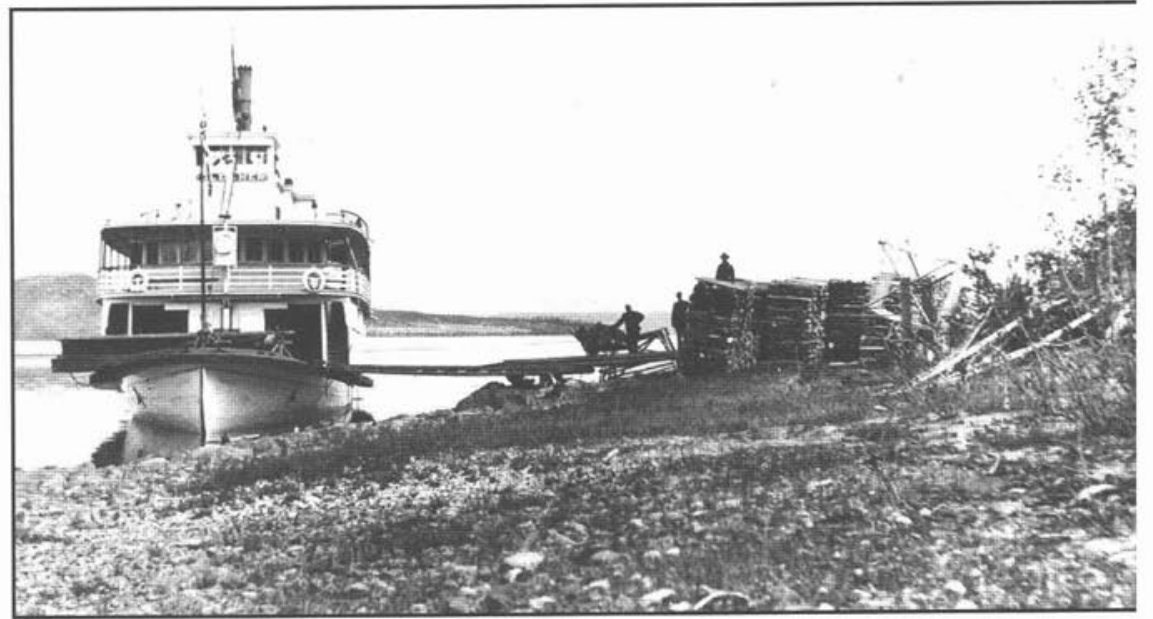

lengths. Wood was piled $6^{\prime}$ high and $4^{\prime}$ wide in double tiers. When sternwheelers docked for wood, a gangplank was put ashore, and wood was loaded on a little two-wheel hand "truck up" and wheeled on board. The wood was loaded as fast as possible and crews could load up to 16 cords in 40 minutes. Usually, 8 to 15 cords were taken per stop, depend- ing on the cargo space. During this peri od from 1898 to 1956, upwards of $30 \mathrm{C}$ 000 cords of fuelwood were consumec by sternwheelers along the Yukon River

Adapted from History of Logging in the Yukon: 1896 - 1970 Volume I, Norther Design Consultants, Canada/Yukon Eco nomic Development Agreement, March 199: 